\title{
DESCRIPTION AND BIOLOGIC NOTES ON A TIPHIA (HYMENOPTERA: SCOLIIDAE) FROIM HAITI
}

By George N. WolcotT, Entomologist, Agricultural Experiment Station, Río Piedras, P. R.

The normal scarcity of white grubs in cultivated fields in Haiti seemed most remarkable to one accustomed to their former great abundance in Puerto Rico. To be sure, the introduction of the giant Surinam toad, Bufo marinus L., into Puerto Rico from Barbados and Jamaica, and its rapid increase in numbers, largely feeding on May beetles (which are the adults of white grubs), has recently so greatly reduced the numbers of white grubs to be found in the cane fields of Puerto Rican lowlands (3) that conditions in the two countries now appear substantially similar. But until a few months ago, no introduced Surinam toad was present in Haiti, and the native toad of Haiti, Bufo gutturosus Latreille, was no more noticeably abundant than the comparable native toad of Puerto Rico, Bufo lemur Cope. The little burrowing owl, Speyotyto cunicularia troglodytes Wetmore \& Swales, quite abundant in Hispaniola, but not present in Puerto Rico, may be a considerable factor in reducing the number of May beetles, altho the only stomach contents record gives no indication that the owl eats this particular kind of beetle (2). Indeed, the most obvious factor in white grub control in Haiti is the abundance of the parasitic wasps belonging to the genus Tiphia.

In all the years that numerous entomologists have been collecting insects since the time of Stahl and Gundlach, only four specimens of Tiphia, all of which now repose in the U. S. National Museum, have been collected in Puerto Rico. In Haiti, on the contrary, several individual collections of adults of both sexes were made by the writer from time to time at various localities in the lowlands, and the number to be seen at Kenscoff the first time it was visited was so large that the actual number of specimens collected can hardly give a correct impression of the abundance of Tiphia. Subsequent visits only served to confirm this preliminary observation of its abundance in the mountains of Haiti. While the wasps occur on various plants, and feeding at various flowers, they greatly prefer those of the wild parsnip, Pastinaca sativa L., or the minute droplets of honey dew to be found on sooty mold blackened leaves of guava 
bushes infested with the green scale, Coccus viridis Green. They are to be noted feeding only in the bright sunshine, and appear to be more abundant and larger in size at the higher altitudes, specifically at Kenscoff (elevation 1,450 meters) up to the pass on the old trail to Furcy. The records of former collections, copied from specimens and the accession cards of the Division of Entomology at Damien, are as follows:

FEMALES

\begin{tabular}{|c|c|c|c|c|c|}
\hline $\begin{array}{l}\text { Haiti } \\
\text { Acc. } \\
\text { No. }\end{array}$ & Locality & Date & Host & Collector & $\begin{array}{c}\text { Number } \\
\text { of } \\
\text { Specimens }\end{array}$ \\
\hline \multirow[t]{5}{*}{$58-27 \ldots$} & Mt. Puilsboreau.......... & May $28,1927 \ldots \ldots$ & Wild carrot... & GNW. & 1 \\
\hline & Post Chaubert, Le Trou.. & Nov. $10,1927 \ldots \ldots$ & & GNW. & 1 \\
\hline & Kenscoff $\ldots \ldots \ldots \ldots \ldots \ldots$ & Nov. $23,1927 \ldots$. & Pastinaca. & GNW. & 2 \\
\hline & Kenscoff.............. & Jan. $5,1928 \ldots \ldots \ldots$ & Pastinaca. & GNW $\ldots \ldots$ & 1 \\
\hline & $\ldots \ldots \ldots \ldots \ldots$ & May $10,1927 \ldots \ldots$ & Cabbage... & E. Ducasse. . & 1 \\
\hline $174-28 \ldots$ & Kenscoff............... & March $14,1928 \ldots$ & $\ldots \ldots \ldots \ldots \ldots$ & E. Ducasse... & 2 \\
\hline $118-33$. & Morne La Selle... & $\begin{array}{l}\text { Aug. } 9,1928 \ldots \ldots \ldots \\
\text { Sept. } 1933 \ldots \ldots \ldots\end{array}$ & & A. Audant.... & $\begin{array}{l}2 \\
1\end{array}$ \\
\hline $74-34 \ldots$ & Morne La Selle... & June, $1934 \ldots$ & & A. Audant... & 1 \\
\hline
\end{tabular}

\section{MALES}

\begin{tabular}{|c|c|}
\hline & 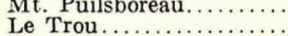 \\
\hline $59-27 \ldots$ & Kenscoff . .............. \\
\hline & Port-au-Prince............ \\
\hline $171-2$ & $\begin{array}{l}\text { Kenscoff } \ldots \ldots \ldots \ldots \ldots \ldots \\
\text { Kenscoff. .............. }\end{array}$ \\
\hline $59-28 \ldots$. & $\begin{array}{l}\text { Port-au-Prince } \ldots \ldots \ldots \ldots \ldots \\
\text { Mirebalais } \ldots \ldots \ldots \ldots \ldots \ldots \ldots \\
\text { Hinche } \ldots \ldots \ldots \ldots \ldots \ldots \ldots \\
\text { Kenscoff } . . . \ldots \ldots \ldots \ldots \ldots\end{array}$ \\
\hline $104-33 \ldots$ & Morne La Selle $\ldots . \ldots \ldots \ldots$. \\
\hline $74-34 \ldots$ & Morne La Selle............ \\
\hline
\end{tabular}

Nov. $9,1927 \ldots$. Nov. $10,1027 . .$. Guava. April, $1927 . . . \ldots$.... Pastinaca Nov. 23, 1927 . Jan. 12, 1928 . March 14, 1928 A pril 4 \& 26, 1927. May, 1928. August 9, 1928. August 30, 1930 August 24, 1930. Sept., 1933 June, 1934

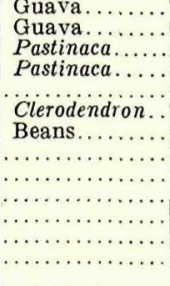

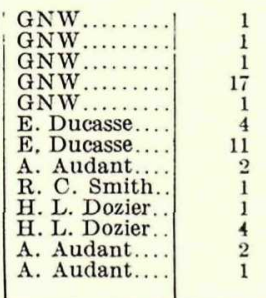

A study of the specimens remaining in the collection at Damien, together with fresh material collected at Kenscoff in December 1937, indicates that all represent but a single species, for which the name hispaniolae is proposed. This species may be characterized as follows :

\section{Tiphia hispaniolae sp. nov.}

Female.-Entirely black, polished, length $15 \mathrm{~mm}$; head, basal segment of antenna, anterior dorsal pronotum, scutum, legs and posterior margins of abdominal segments with long silvery hairs. Head, coarsely but unevenly punctate, as is also anterior pronotum, with a line of deep punctures almost coalescing to form a deep transverse groove with posteriorly pointing hairs, posterior and lateral pronotum polished and impunctate. Notauli of scutum ending in deep punctures before base, no antero-medial groove, scutum coarsely but sparingly punctate. Preapical groove on posterior aspect of mesepisternum. Prepodeal areola almost twice as long as broad, anterior lateral margins slightly curved outwards, posteriorly straight and parallel, median carina not reaching. apex. Median carina of posterior aspect extending nearly to apex. Wings translucent black, lighter in marginal and radial cells, with transparent lines 
paralleling the opaque black veins to outer margin. Second intercubital vein somewhat sinuous, joining the radius in a broadly rounded angle. Cubital mark present in large individuals, only at marginal vein in smaller specimens. Hind basitarus not grooved, major calcarium of hind tibia only slightly wider towards middle than at base. First tergite of abdomen with very deep preapical groove, all tergites anteriorly lightly punctured, postmedially almost impunctate, a transverse row of punctures near apex. Pygidium deeply impuctate only on basal half.

Described from 33 specimens, Haiti \& Puerto Rico Acc. No. 133-37, collected between Kenscofi and Furcy, Haiti, elevation about 1,700 meters, December 5, 1937 by George N. Wolcott.

Male.-Black, polished, length $9 \mathrm{~mm}$., punctures and pubescence much finer than in female, in this respect quite unlike Tiphia argentipes of Cuba, which Cresson (1) describes as "more slender and hairy (than the female); the punctures of the mesothorax and abdomen deeper and closer." Radial cell greatly exceeding second cubital, basal half and apical margin of forewing hyaline, elsewhere fuscous, basal third only not pubsecent, veins black. No denticle on fifth sternite of abdomen. First tergite with deep preapical groove and carina, also a prominent median transverse carina. Cresson mentions no such median carina, in his description of argentipes; Miss Sandhouse states that it does not occur in the Puerto Rican males; it does not appear on a single male collected at Santiago, República Dominicana, by S. del Rosario on March 26, 1936, and now in the collection of the College of Agriculture at Mayagüez, P. R., loaned to me for study by Dr. Stuart T. Danforth; therefore this character appears to be distinetive for the males of this species, separating it from others of the Greater Antilles.

Described from a single specimen (TYPE) out of 5 examples, Haiti \& Puerto Rico Acc. No. 136-37, collected at Kenscoff, Haiti, December 13, 1937 by George N. Wolcott, compared with 12 examples, Haiti Acc. No. 59-27, collected at Kenscoff, November 23, 1927 by George N. Wolcott. Type and accompanying females for the U. S. National Museum, others for the British Museum, the bulk of the material in the collection at the Agricultural Experiment Station at Río Piedras, P. R. and at Damien, Haiti.

The May beetles of Haiti vary tremenduously in size (4); and no information is available as to which of these several species of white grub is attacked by Tiphia hispaniolae. It is possible, however, that despite the selectivity displayed by continental species of Tiphia, different instars of approximately the same size of most or all of the grubs of Haiti are attacked by the females of the single species of Tiphia found there. If the Haitian Tiphia is in fact so unselective in its attack on white grubs, presumably it would attack other species of white grubs in an environment similar to that of Haiti. This would make it a most valuable addition to the fauna 
of Puerto Rico, more especially at the higher altitudes where it thrives, but where Bufo marimus does not and is thus of so little value in white grub control.

\section{Literature :}

1. Cresson, E. T., "On the Hymenoptera of Cuba." Proc. Ent. Soc. Philadelphia, pp. 1-200 (see p. 117), January, 1865.

2. Danforth, S. T., "Notes on the Birds of Hispaniola." Auk, 46: 358-375 (see p. 368). July, 1929.

3. Wolcott, G. N., "The White Grub Problem in Puerto Rico." Fifth Congress, International Soc. Sugar Cane Technologists, pp. 445-456, fig. 5, ref. 11. Brisbane, Queensland, 1936.

4. Wolcott, G. N., "The May Beetles of Haiti (Scarabaeidae: Coleoptera)." Proc. Ent. Soc. Washington, 30(2) : 21-29, fig. 3, ref. 5. March 24, 1928. 